Kredo 4 (2020)
KREDO: Jurnal Ilmiah Bahasa dan Sastra
Terakreditasi Sinta 4 berdasarkan Keputusan Direktorat
Jenderal Penguatan Riset dan Pengembangan,
Kementerian Riset, Teknologi dan Pendidikan Tinggi
Republik Indonesia
Nomor: 23/E/KPT/2019. 08 Agustus 2019
https://jurnal.umk.ac.id/index.php/kredo/index

\title{
CAMPUR KODE DALAM TUTURAN VIDEO BLOG YOUTUBE AGUNG HAPSAH “FINTECH”
}

\author{
Arini Febiantika Nirmala ${ }^{1}$, Febriyanti ${ }^{2}$, Evi Chamalah ${ }^{3}$ \\ arinifebiantika@std.unissula.ac.id
}

Universitas Islam Sultan Agung, Indonesia

Info Artikel Sejarah Artikel

\author{
Diterima \\ 8 Juni 2020 \\ Disetujui \\ 21 September 2020 \\ Dipublikasikan \\ 28 Oktober 2020
}

Keywords code mixing, video, youtube

\section{Kata Kunci}

campur kode, video, youtube
: :

The purpose of this research is to describe the form of code mixing in the video. This research is a qualitative descriptive research. This research used a free and involved method. The resulted in this study are (1) there are data which are mixed forms of code where there is insertion of elements in the form of words is 8 data which is the data is an insertion of elements in the form of words in two languages namely Indonesian, English. (2) in the Agung youtube video there is data which is a form of code mixing where there is insertion of elements in the form of a phrase as much as 8 data which is the data is the insertion of elements in the form of words in two languages namely Indonesian and English. (3) there is data which is a form of code mixing which is insertion of elements in the form of idioms or expressions is 1 data. The data is an insertion of tangible elements in two languages namely Indonesian and English. (4) in the video contained data which is a form of code mixing where there is insertion of elements in the form of clause is 2 data which is an insertion of elements in the form of words in two languages namely Indonesian, English.

Abstrak

\section{PENDAHULUAN}

Indonesia merupakan negara yang masyarakatnya merupakan gabungan dari keberagaman budaya. Ditemukan berbagai ragam bahasa, di mana ragam bahasa tersebut digunakan sebagai media dan juga sarana komunikasi dengan masyarakat lainnya. Seperti yang diketahui bahasa itu sendiri digunakan sebagai alat komunikasi dan dalam bermasyarakat bahasa sering kali digunakan sebagai kode, baik dari segi bentuk, maupun gaya bahasanya. Bahasa juga merupakan salah satu faktor yang memiliki pengaruh penting dalam kehidupan sehari-hari dan dalam berinteraksi. Namun bukan hanya bahasa, melainkan ada pula banyak hal yang sangat berpengaruh dalam kehidupan sehari-hari, salah satunya komunikasi. Masyarakat membutuhkan sebuah komunikasi untuk berinteraksi. Dalam berinteraksi tidak sedikit masyarakat menggunakan alat perantara untuk menyampaikannya. Salah satunya 


Kredo 4 (2020)
KREDO: Jurnal Ilmiah Bahasa dan Sastra
Terakreditasi Sinta 4 berdasarkan Keputusan Direktorat
Jenderal Penguatan Riset dan Pengembangan,
Kementerian Riset, Teknologi dan Pendidikan Tinggi
Republik Indonesia
Nomor: 23/E/KPT/2019. 08 Agustus 2019
https://jurnal.umk.ac.id/index.php/kredo/index

media sosial, masyarakat memilih media sosial menjadi sebuah alat untuk berinteraksi, mengekspresikan diri, mendapatkan sebuah informasi dan masih banyak lagi. Karena zaman mengalami perkembangan, media pun tak kalah berkembang pula salah satunya youtube.

Youtube merupakan sebuah situs laman yang sangat populer dikalangan masyarakat Indonesia. Youtube memiliki berbagai jenis video, seperti vlog, music video, short movie, talk show, dan lainlain. Youtube memberikan fasilitas bagi penonton secara gratis. Youtuber merupakan orang yang membuat video dan mengunggahnya ke dalam situs laman "Youtube".

Youtube menjadi salah satu pilihan yang digemari serta tak asing lagi bagi masyarakat Indonesia, youtube berada di peringkat ketiga setelah Google dan TribunNews. Youtube adalah sebuah media sosial yang berisi kumpulan video (audio visual) masyarakat dapat mendengar serta melihat di dalam waktu yang sama, sehingga akan lebih mudah dalam menerima pesan yang disampaikan. Video yang terdapat dalam youtube sangat bermacam-macam, mulai dari video blog, short movie, musik video, dan lain-lain.

Salah satu jenis video yang terdapat di youtube yakni video blog. Video Blog hampir sama dengan blog, hanya berbeda pada segi medianya, jika blog berupa tulisan, namun $v \log$ berupa video. Video blog atau vlog merupakan sebuah alat untuk menyampaikan sebuah aspirasi, menuangkan sebuah ide, dan kreativitas. Tentunya, pada pembuatan sebuah vlog, amat membutuhkan sebuah konsistensi dalam berbagai bentuk, misalnya seperti konten, ide, setting, hingga proses editing.

Seseorang yang membuat sebuah vlog, disebut vlogger. Para vlogger youtube memiliki sebuah kebebasan dalam menuangkan ide atau pikiran mereka. Kebebasan tersebut dapat berbentuk pemilihan ide, bahasa, konten, dan sebagainya. Vlog sendiri memiliki beberapa bentuk video, seperti video traveling, video tutorial, video, daily vlog, dan lain-lain.

Pada masa kini, vlog menjadi video yang digemari oleh masyarakat Indonesia, dengan munculnya Youtubers Indonesia yang sangat kreatif dalam menuangkan ide dalam videonya. Youtubers tersebut seperti Chandra Liow (tim2one) yang memiliki video dengan sinematografi yang sangat baik, Baim Wong yang memiliki video dengan konten positif, Agung Hapsah memiliki gaya yang berbeda dalam menyajikan videonya. Ia menggunakan kemampuan editing dan teknik sinematografinya yang sangat baik. Setiap Agung mengunggah sebuah video, video tersebut selalu trending. Walaupun rutinitas menggunggah video, Agung termasuk jarang dan tidak sesering youtubers lain.

Konten-konten dengan kreativitas yang tinggi akan memepengaruhi jumlah subscriber dan jumlah penonton video tersebut. Namun, tak lupa juga bahasa di dalam sebuah vlog sangat berpengaruh. Karena, bahasa memiliki peran yang sangat penting didalam sebuah komunikasi. Agar komunikasi tersebut tersampaikan secara lengkap, seorang youtuber harus menggunakan bahasa yang baik. 


\begin{tabular}{|c|c|c|} 
Kredo 4 (2020) \\
KREDO: Jurnal Ilmiah Bahasa dan Sastra \\
Terakreditasi Sinta 4 berdasarkan Keputusan Direktorat \\
Jenderal Penguatan Riset dan Pengembangan, \\
Kementerian Riset, Teknologi dan Pendidikan Tinggi \\
Republik Indonesia \\
Nomor: 23/E/KPT/2019. 08 Agustus 2019 \\
https://jurnal.umk.ac.id/index.php/kredo/index
\end{tabular}

Bahasa yang baik bukan berarti bahasa yang resmi dan formal. Bahasa yang baik merupakan bahasa yang dapat diterima dengan baik oleh lawan bicara. Di mana bahasa itu sendiri memiliki pengertian menurut Chaer dan Agustina (2014: 11) Bahwasannya bahasa merupakan sebuah sistem yang memiliki arti bahwa bahasa terbentuk dari beberapa unsur yang berstuktur tetap dapat dirumuskan.

Bahasa yang tidak asing lagi di Indonesia adalah yang pertama yakni Bahasa Indonesia yang dijadikan sebagai bahasa persatuan Indonesia, yang kedua yakni Bahasa daerah yang digunakan masyarakat Indonesia sebagai bahasa sehari-hari seperti bahasa Jawa, bahasa Sunda, bahasa Betawi, dan lain-lain, dan yang ketiga yakni bahasa asing yakni bahasa Inggris, bahasa Jepang, bahasa Melayu, dan lain-lain. Penggunaan bahasa asing itu sendiri kerap dijadikan bahasa sehari-hari. Contoh kecil untuk remaja yang bertempat tinggal di Ibu kota biasanya lebih kerap berbicara menggunakan 2 bahasa yaitu bahasa Indonesia dan di campur dengan bahasa asing (lebih sering bahasa Inggris), "Orang yang dapat menguasai dua bahasa disebut juga bilingual, selain bilingual, ada lagi yakni multilingual yakni seseorang yang dapat menguasai lebih dari dua bahasa yang ia gunakan dengan cara bergantian.

Sependapat dengan Suhardi (2009: 42) bilingualisme digunakan seseorang yang memakai dan menguasai dua bahasa sebagai masyarakat bahasa. Seseorang yang sedang berinteraksi menggunakan kode-kodean harus dimengerti oleh pihak yang diajak berinteraksi. Pengkodean tersebut harus melalui proses yang baik oleh orang yang mengkode dan orang yang menerima kode tersebut. Secara alamiah kode merupakan hasil dari alat bicara seseorang. Bahasa yang digunakan oleh masyakarat bilingualisme menimbulkan adanya pengaruh pada bidang lingusitik, yang dapat memunculkan peristiwaperisriwa bahasa.

Ada dua jenis yang terdapat pada masyarakat multilingualisme yakni sebuah kontak bahasa yang telah terjadi yakni campur kode dan alih kode, namun di sini hanya akan membahas satu permasalahan bahasa, yakni campur kode. Campur kode merupakan sebuah kode yang diberikan oleh penutur kepada lawan tutur yang memiliki tujuan untuk menyampaikan sebuah maksud. Menurut Suwito 1983: 78 campur kode dibagi menjadi beberapa macam berdasarkan kebahasaan yang terlibat. Diantaranya 1) Penyisipan unsur-unsur yang berupa kata, 2) Penyisipan unsur-unsur yang berupa frase, 3) penyisipan unsur-unsur berupa baster, 4) Penyisipan unsur-unsur yang berupa perulangan, 5) Penyisipan unsur-unsur yang berupa ungkapan atau idiom, 6) Penyisipan unsur-unsur yang berupa klausa

Campur kode dapat terjadi, jika seseorang menyisipkan sebuah bahasa asing ke dalam pembicaraan bahasa Indonesia. Ciri khas dari campur kode yakni saat adanya situasi yang santai dalam pembicaraan tersebut. Campur kode tak hanya terjadi pada dunia nyata saja, namun didalam media seperti Youtube juga sering terjadi. Banyak Vlogger yang tanpa sengaja melakukan sebuah tuturan campur kode.

Seperti halnya youtubers Agung Hapsah, penggunaan bahasa pada video 


Kredo 4 (2020)
KREDO: Jurnal Ilmiah Bahasa dan Sastra
Terakreditasi Sinta 4 berdasarkan Keputusan Direktorat
Jenderal Penguatan Riset dan Pengembangan,
Kementerian Riset, Teknologi dan Pendidikan Tinggi
Republik Indonesia
Nomor: 23/E/KPT/2019. 08 Agustus 2019
https://jurnal.umk.ac.id/index.php/kredo/index

blog Agung Hapsah dapat dikelompokkan didalam bermacammacam bentuk bahasa. Hingga akhirnya bahasa yang digunakan oleh youtubers tersebut dapat di analisis melalui cara kebahasaan. Salah satu permasalahan yang dapat di analisis dari berbagai youtubers yakni tuturannya, yang mana tuturan tersebut berisi sebuah bilingualism yakni terdapat dua bahasa dalam satu tuturan. Agung Hapsah menyajikan sebuah video yang berisi bilingualism, yang mana Ia bertutur dalam bahasa Indonesia dan diselingi bahasa Inggris. Dalam video "Fintech" juga terdapat CEO Gopay yakni Aldi Haryopratomo. Aldi Haryopratomo juga melakukan campur kode dalam tuturannya. Bahasa pada video youtube Agung Hapsah sangat menarik untuk dijadikan sebuah penelitian karena menggunakan lebih dari satu bahasa.

Agung Hapsah adalah seorang Youtuber yang besar di Australia. Saat pertama kali Ia datang ke Indonesia Ia mengalami Culture Shock. Hal tersebut menjadikan Agung Hapsah memiliki kemampuan berbahasa Inggris yang baik. Bahkan saat Ia berada di Indonesia, Ia menggunakan bahasa Indonesia semi formal. Penguasaan dua bahasa, Agung Hapsah Campur kode itu sendiri merupakan sebuah penyisipan bahasa satu didalam bahasa inti dan tidak memiliki suatu fungsi yang sudah jelas didalam sebuah tuturan dalam berkomunikasi.

Berdasarkan latar belakang yang sudah diuraikan diatas, sehingga perlu adanya penelitian yang dilakukan terhadap salah satu video blog dalam youtube Agung Hapsah yang mencakup campur kode. Hingga akhirnya peneliti mendapatkan judul yakni "Campur Kode dalam Tuturan video Blog Youtube Agung Hapsah "Fintech".

\section{KAJIAN TEORI}

\section{Kode}

Menurut Suwito (1985: 67) Kode ditujukan untuk menyatakan satu diantara varian di dalam kumpulan kebahasaan. Selain kode sering dikenal juga beberapa varian lain seperti varian regional, varian kelas sosial, gaya, ragam dan varian kegunaan. Rahardi (2010:55) megelompokkan kode sebagai suatu sistem tutur yang proses unsur bahasanya memiliki kriteria khusus dengan latar belakang penutur, hubungan penutur dengan lawan bicara dan keadaan tutur yang ada.

Adapun menurut KBBI (dalam Munandar Aris 2018) kode merupakan symbol yang dapat berupa tulisan atau kata-kata yang disetujui sebagai sebuah tujuan.

\section{Campur Kode}

Rokhman 2013:38 menyatakan bahwa campur kode merupakan penggunaan dua bahasa atau lebih dengan saling menyisipkan bagianbagian bahasa yang satu kedalam bahasa yang lain, yang mana bagian-bagian bahasa atau variasi-variasi yang berada didalam bahasa lain tidak lagi mempunyai tersendiri. Campur Kode merupakan pemakaian dua bahasa atau lebih atau jenis bahasa secara bebas antara orang-orang yang kita kenal dengan akrab. Dalam keadaan berbahasa yang formal, kita bisa dengan bebas menyatukan kode khususnya jika ada 


Kredo 4 (2020)
KREDO: Jurnal Ilmiah Bahasa dan Sastra
Terakreditasi Sinta 4 berdasarkan Keputusan Direktorat
Jenderal Penguatan Riset dan Pengembangan,
Kementerian Riset, Teknologi dan Pendidikan Tinggi
Republik Indonesia
Nomor: 23/E/KPT/2019. 08 Agustus 2019
https://jurnal.umk.ac.id/index.php/kredo/index

ungkapan yang tidak dapat disampaiakan dalam bahasa lain (Suwandi, 2008:87).

Menurut Kridaklasana 2008:40 berpendapat bahwa campur kode merupakan pemakaian satuan bahasa guna menambah model dan macam bahasa dari bahasa satu ke bahasa lain.

Menurut Hestiyana 2013:40 campur kode merupakan penggunaan dua atau lebih bahasa yang keduanya saling berhubungan secara selaras. Sedangkan Mackey 1962:12 dan Fishman 1975:73 (dalam Muharam Rijal 2011) berpendapat bahwa sesuai dengan sosiolingiustik umum, campur kode adalah pemakaian dua bahasa dalam sebuah perkumpulan yang di lakukan oleh penutur.

Menurut Haugen campur kode adalah mengetahui dua bahasa, sedangkan menurut Boemfild (1958:56) campur kode adalah kecakapan dalam penggunaan dua bahasa yang dikuasai dengan baik oleh si penutur.

Chaer (2010:114) berpendapat bahwa campur kode merupakan lambang dasar yang di pakai dan mempunya kegunaan dan sistemnya. Dan Menurut Surwito (1985), campur kode sering terjadi dalam kondisi senggang atau karena sering dilakukan secara berulangulang. Dan Menurut Saddono 2012:75 (dalam Ruyaldi, dkk) menyatakan bahwa campur kode merupakan pemakaian dua atau lebih bahasa yang terjadi hubungan timbal balik antara keduanya.

Menurut Sumarsono (2007) menyatakan bahwa bilingualism atau campur kode merujuk pada keadaan pemahaman bahasa kedua dengan kadar pemahaman yang sama dengan si penutur aslinya.
Menurut Suwandi 2010:87 menyatakan bahwa campur kode merupakan dua atau lebih bahasa yang digunakan secara bebas dalam interaksi terhadap orang-orang yang kita kenal. Adapula Pieter Muysken 2000 memaparkan bahwa campur kode memiliki 3 karakteristik, yaitu penyisipan, peralihan, dan leksikalasi kongruen. Pada karakteristik yang pertama yaitu penyisispan Muysken (2000:61) yaitu mencantumkan sebuah bagian penting, bagian itu adalah satuan sintaksis, seperti unsure leksikon atau frase.

Ohoiwutun 1997:66 berpendapat bahwa campur kode merupakan pemakaian dua atau lebih bahasa yang digunakan seseorang atau masyarakat sering disebut juga bilingualism atau kedwibahasaan.

Nababan (1991:32) menyatakan bahwa campur kode merupakan keadaan seseorang yang menyatukan dua bahasa tanpa ada sebuah perihal dalam situasi berbahasa yang menuntut percampuran bahasa itu. Sependapat dengan Kridalaksana (1993:35) yang menyatakan bahwa campur kode merupakan pemakaian satuan bahasa ke bahasa lain untuk memperluas gaya bahasa, termauk pemakaian kata, klausa, idiom, sapaan dan lainya.

Aslinda dan Syafyahya 2007 memaparkan bahwa karakteristik pada campur kode yakni kejadian yang terjadi dalam keadaan tidak resmi.

Khotimah 2014:96 memaparkan bahwa campur kode terbagi atas campur kode luar dan campur kode dalam. Yang tergolong campur kode dalam yakni apabila berasal dari bahasa daerah atau bahasa asli penutur. 


Kredo 4 (2020)
KREDO: Jurnal Ilmiah Bahasa dan Sastra
Terakreditasi Sinta 4 berdasarkan Keputusan Direktorat
Jenderal Penguatan Riset dan Pengembangan,
Kementerian Riset, Teknologi dan Pendidikan Tinggi
Republik Indonesia
Nomor: 23/E/KPT/2019. 08 Agustus 2019
https://jurnal.umk.ac.id/index.php/kredo/index

Menurut Suwito (1996: 78-80) campur kode terdapat beberapa bentuk, yakni:

1) penyisipan unsur-unsur yang berbentuk kata,

2) penyisipan unsur-unsur yang berbentuk frasa,

3) penyisipan unsur-unsur yang berbentuk baster,

4) penyisipan unsur-unsur yang berbentuk pengulangan kata,

5) penyisipan unsur-unsur yang berbentuk idiom atau ungkapan,

6) penyisipan unsur-unsur yang berbentuk klausa.

\section{Youtuber Agung Hapsah}

Youtube merupakan sebuah situs laman yang sangat populer dikalangan masyarakat Indonesia. Youtube memiliki berbagai jenis video, seperti vlog, music video, short movie, talk show, dan lainlain. Youtube memberikan fasilitas bagi penonton secara gratis. Youtuber merupakan orang yang membuat video dan mengunggahnya ke dalam situs laman "Youtube".

Seseorang yang memiliki kualitas video dengan sinematografi yang luar biasa, konten yang menarik, dan bermanfaat adalah youtuber yang di incar semua masyarakat Indonesia, sebut saja Agung Hapsah. Agung Hapsah merupakan seorang konten kreator dengan skil editing dan sinematografi yang sangat baik. Ia memiliki darah Indonesia dan besar di Australia sehingga memiliki kualitas bahasa Inggris yang sangat baik.

Agung Hapsah merupakan seseorang yang berprestasi, diantara prestasi tersebut yakni saat masih menjadi siswa sekolah yaitu Ia mengikuti sebuah lomba National School Debating Championship, acara tersebut dilaksanakan di Kalimatantan Timur pada tahun 2016 dan pada saat itu Ia mendapatkan suatu gelar yang membanggakan, yakni pembicara terbaik. Lalu, Ia juga mengikuti sebuah lomba festival lomba seni siswa nasional pada kategori short movie atau film pendek. Tak heran jika kemampuan editing dan sinematografinya sangat baik.

\section{METODE PENELITIAN}

Penelitian ini menggunakan metode kualitatif. Menurut Sugiyono (dalam Widianto) menjelaskan bahwa metode kualitatif dipakai untulk memperoleh data yang luas, suatu data yang berisi sebuah makna. Data yang telah tertulis merupakan sebuah hasil dari metode kualitataif. Jenis penelitian yang digunakan yakni penelitian deskriptif dengan pendekatan kualitatif. Tujuan dari penelitian yang menggunakan jenis data penelitian deskriptif yakni untuk menggambarkan suatu kejadian yang benar adanya dari sebuah objek, hingga akhirnya peneliti mendapatkan data yang bersifat objektif mengenai keadaan yang sebenarnya. Penelitian ini memiliki tujuan untuk mendeskripsikan Campur Kode dalam Tuturan video Blog Youtube Agung Hapsah "Fintech".

Analisis data menggunakan metode deskriptif dengan pendekatan kualitatif. Data berupa tuturan yang mengandung campur kode yang ditemukan dalam video Youtube Agung Hapsah yang berjudul "fintech". Sumber data pada penelitian ini yakni video Youtube Agung Hapsah yang berjudul "Fintech". 


Kredo 4 (2020)
KREDO: Jurnal Ilmiah Bahasa dan Sastra
Terakreditasi Sinta 4 berdasarkan Keputusan Direktorat
Jenderal Penguatan Riset dan Pengembangan,
Kementerian Riset, Teknologi dan Pendidikan Tinggi
Republik Indonesia
Nomor: 23/E/KPT/2019. 08 Agustus 2019
https://jurnal.umk.ac.id/index.php/kredo/index

Teknik pengumpulan data menggunakan teknik simak dan teknik catat. Menurut Sudaryanto (2016: 204) metode simak dipakai untuk mendapatkan data dengan cara menyimak pada penggunaan bahasa. Metode simak juga mempunyai beberapa teknik, yakni teknik simak libat cakap, teknik simak lbebas libat cakap, teknik sadap, teknik rekam dan teknik catat.

Peneliti menggunakan simak bebas libat cakap dalam mengamati atau menyimak video Agung Hapsah, yang dilakukan dengan mengamati penggunaan bahasanya yang berisi unsur campur kode sebagai data penelitian. Setelah dilakukannya kegiatan menyimak diteruskan dengan teknik catat, kegiatan ini mencatat seluruh tuturan yang ada dalam video blog youtube Agung Hapsah yang berjudul "Fintech" tuturan yang ditemukan harus mengandung unsur campur kode didalamnya.

Dalam penelitian ini peneliti menggunakan metode yang sesuai dengan langkah-langkah dalam tahapan pelaksanaannya. Yakni yang pertama tahap pengumpulan data, yang kedua tahap analisis data, yang ketiga yakni tahap pemaparan hasil analasis (Sudaryanto, 1988: 57).

\section{HASIL DAN PEMBAHASAN}

Peneliti melakukan penelitian ini untuk mendapatkan data yang berupa campur kode dalam video youtube Agung Hapsah yang berjudul "fintech", penelitian ini menguraikan data hasil penelitian. Data yang ditemukan hanya berupa kata, frasa, idiom, dan klausa. Campur kode yang dituturkan oleh
Agung Hapsah dikarenakan Ia hidup dan besar di negara asing yang berbahasa Inggris.

1. Penyisipan unsur yang berwujud kata

Temuan data 1:

"dia seorang surfer"

Pada data yang telah ditemukan di atas merupakan campur kode yang melibatkan dua bahasa, yakni bahasa Indonesia dan bahasa Inggris yang mana bahasa Inggris dicampurkan ke dalam bahasa Indonesia. Menurut penyisipan yang ada pada data di atas dapat disebutkan bahwa campur kode yang dipakai adalah kata surfer (peselancar) yang berasal dari bahasa inggris. Disini penutur menggunakan bahasa Inggris yang merupakan bahasa Asing yang Ia kuasai dimaana Ia besar di lingkungan yang menggunakan bahasa Inggris.

Temuan data 2:

"And kalo kita ga ngerubah mindset kita bahwa"

Pada data yang ditemukan di atas merupakan campur kode yang memuat dua bahasa yakni bahasa Indonesia dan bahasa Inggris yang mana bahasa Inggris dicampurkan ke dalam bahasa Indonesia. Menurut penyisipan, diatas dapat dikatakan bahwa data yang digunakan ialah and yang berarti (dan) dan data mindset yang berarti pikiran. Penutur tersebut dapat secara fasih dikarenakan penutur tersebut telah menguasai bahasa Asing seperti salah satunya yakni bahasa Inggris. Yang mana, kata tersebut jika dikatakan dalam bahasa Indonesia menjadi "dan kalo kita ga ngerubah pikiran kita bahwa". 


Kredo 4 (2020)
KREDO: Jurnal Ilmiah Bahasa dan Sastra
Terakreditasi Sinta 4 berdasarkan Keputusan Direktorat
Jenderal Penguatan Riset dan Pengembangan,
Kementerian Riset, Teknologi dan Pendidikan Tinggi
Republik Indonesia
Nomor: 23/E/KPT/2019. 08 Agustus 2019
https://jurnal.umk.ac.id/index.php/kredo/index

Temuan data 3:

"tapi untuk merchant? Penjualpenjual yang ada di jalan, dan pake gopay bener-bener bisa merubah hidup"

Pada data diatas yang ditemukan merupakan campur kode yang menyisipkan unsur berwujud kata. Kata data tersebut memuat dua bahasa yakni bahasa Indonesia dan bahasa Inggris yang mana bahasa Inggris dicampurkan ke dalam bahasa Indonesia. Merchant merupakan kata yang memiliki arti (pedagang). Data tersebut menjelaskan bahwa penjual ataupun pedagangpedagang yang berada dijalanan jika menggunakan gopay, akan menjadikan lebih mudah. Mereka bisa menabung tanpa perlu ke bank, tanpa harus susah mencari uang kembalian. Data tersebut jika diterjemahkan ke dalam bahasa Indonesia menjadi "tapi untuk pedagang? Penjual-penjual yang ada di jalan, dan pake gopay bener-bener bisa merubah hidup"

Temuan data 4:

"kita kayak sehari-hari pake gopay paling benefit nya apa?"

Pada data diatas yang ditemukan merupakan unsur yang berwujud kata. Data tersebut memuat dua bahasa yakni bahasa Inggris dan bahasa Indonesia yang mana bahasa Inggris dicampurkan ke dalam bahasa Indonesia. Penutur dapat menuturkan dua bahasa dengan lancar dikarekanan penutur telah menguasai bahasa tersebut dengan baik. Benefit memiliki arti (manfaat). Data tersebut menanyakan manfaat dari memakai gopay. Peristiwa campur kode tersebut terjadi saat penutur menjelaskan beberapa hal mengenai gopay. Jika diterjemahkan ke dalam bahasa Indonesia data tersebut akan menjadi "kita kayak sehari-hari pake gopay, paling manfaatnya apa?

Temuan data 5:

"Gojek punya driver, merchant sama user yang menjadi connector semua adalah gopay"

Pada data di atas yang ditemukan merupakan unsur yang berwujud kata, namun ada beberapa kata di dalam satu data. Meliputi driver (pengendara), merchant (dagangan), user (pengguna), dan connector (penghubung). Data tersebut menjelaskan hubungan antara gojek dan gopay. Data tersebut memuat dua bahasa yakni bahasa Indonesia dan bahasa Inggris yang mana bahasa Inggris dicampurkan ke dalam bahasa Indonesia. data tersebut jika di terjemahkan ke dalam bahasa Indonesia menjadi "gojek punya pengendara, dagangan, sama pengguna yang menjadi penghubung semua adalah gopay".

Temuan data 6:

"sepuluh tahun menjual, Pak Tum bisa merasakan bedanya sekarang versus dulu sebelum ada fintech"

Pada data diatas yang ditemukan merupakan campur kode yang menyisipkan unsur berwujud kata. Kata data tersebut memuat dua bahasa yakni bahasa Indonesia dan bahasa Inggris yang mana bahasa Inggris dicampurkan ke dalam bahasa Indonesia. Versus merupakan kata yang memiliki arti (lawan). Data tersebut menjelaskan bahwa membandingkan sebelum dan sesudah munculnya fintech di Indonesia terhadap penjual yang bernama Pak Tum. Data versus tersebut jika diterjemahkan ke dalam bahasa Indonesia dapat memiliki arti yang berbed seperti berikut "sepuluh tahun menjual, Pak Tum bisa merasakan 


Kredo 4 (2020)
KREDO: Jurnal Ilmiah Bahasa dan Sastra
Terakreditasi Sinta 4 berdasarkan Keputusan Direktorat
Jenderal Penguatan Riset dan Pengembangan,
Kementerian Riset, Teknologi dan Pendidikan Tinggi
Republik Indonesia
Nomor: 23/E/KPT/2019. 08 Agustus 2019
https://jurnal.umk.ac.id/index.php/kredo/index

bedanya sekarang dengan dulu sebelum ada fintech"

Temuan data 7:

"yang tadinya server, web, jadinya apa? Mobile? Right?"

Pada data di atas yang ditemukan merupakan unsur yang berwujud kata, namun ada beberapa kata di dalam satu data. Meliputi mobile (telepon genggam atau gawai), dan right (benar). Data tersebut menjelaskan sejarah layanan fintech di Indonesia. Data tersebut memuat dua bahasa yakni bahasa Indonesia dan bahasa Inggris yang mana bahasa Inggris dicampurkan ke dalam bahasa Indonesia. data tersebut jika di terjemahkan ke dalam bahasa Indonesia menjadi "yang tadinya server, web, jadinya apa? Gawai? Benarkan?"

Temuan data 8:

"Muncul website yang sangat popular"

Pada data diatas yang ditemukan merupakan campur kode yang menyisipkan unsur berwujud kata. Kata data tersebut memuat dua bahasa yakni bahasa Indonesia dan bahasa Inggris yang mana bahasa Inggris dicampurkan ke dalam bahasa Indonesia. Website merupakan kata yang memiliki arti (laman). Data tersebut sebelumnya sudah menguraikan sejarah dari layanan teknologi keuangan di Indonesia. Data tersebut jika diterjemahkan ke dalam bahasa Indonesia menjadi "muncul laman yang sangat popular".

\section{Penyisipan unsur yang berwujud}

frasa

Temuan data 9:

"Credit card yang mengganti uang kertas"

Pada data diatas ditemukan jenis data berupa campur kode yang menyisipkan wujud frasa. Data tersebut mengandung dua bahasa yakni bahasa Inggris yang di sisipkan kedalam bahasa Indonesia. Sisipan kata yang di gunakan yaitu Credit card yang memiliki arti (kartu kredit). Data tersebut terjadi adanya penyisipan bahasa berupa credit card yang didasari oleh kebiasaan penutur dalam berkomunikasi akibat pengaruh lingkungan ataupun kebiasaan berkomunikasinya. Data tersebut menjelaskan bahwa pada masa kini uang kertas telah digantikan dengan kartu kredit. Jika data tersbeut di terjemahkan ke dalam bahasa Indonesia menjadi "kartu kredit akan mengganti uang kertas".

\section{Temuan data 10:}

"under water diver"

Data diatas merupakan campur kode yang menyisipkan wujud frasa. Sisipan frasa yang digunakan yaitu Under water diver merupakan frasa yang memiliki arti penyelam. Data diatas menjelaskan bahwa adanya penyisipan bahasa Inggris yang menjelaskan sebuah profesi si teman tutur yang di jelaskan oleh sang penutur. Data tersebut menjelaskan siapakah aldi? Dia adalah seorang penyelam. Data tersebut jika di terjemahkan ke dalam bahasa Indonesia menjadi "penyelam".

Temuan data 11:

"Fintech adalah finance technology"

Data diatas merupakan campur kode yang menyisipkan wujud frasa, yang terdiri dari dua bahasa yakni bahasa Inggris yang di sisipkan kedalam bahasa Indonesia. Finance technology memiliki arti teknologi keuangan. Data tersebut menjelaskan pengertian fintech, fintech yakni finance dan technologi, data 


\begin{tabular}{|c|c|c|} 
Kredo 4 (2020) \\
KREDO: Jurnal Ilmiah Bahasa dan Sastra \\
Terakreditasi Sinta 4 berdasarkan Keputusan Direktorat \\
Jenderal Penguatan Riset dan Pengembangan, \\
Kementerian Riset, Teknologi dan Pendidikan Tinggi \\
Republik Indonesia \\
Nomor: 23/E/KPT/2019. 08 Agustus 2019 \\
https://jurnal.umk.ac.id/index.php/kredo/index
\end{tabular}

tersebut jika di terjemahkan ke dalam bahasa Indonesia adalah "Fintech adalah teknonologi keuangan”.

Temuan data 12:

"Mereka punya akses kepada fiturfitur finance yang sehari-hari kita take for granted"

Data diatas merupakan campur kode berupa wujud frasa. Bahasa Inggris yang disisipkan kedalam bahasa Indonesia. Pada frasa di atas terdapat dua data sisipan bahasa Inggris yakni finance memiliki arti keuangan dan take for granted memiliki arti menerima dengan yakin. Frasa diatas menjalaskan bahwa keuntungan atau uang yang kita terima tidak lain dari orang-orang yang menjadi akses dari kerjasama Gopay. Jika di terjemahkan terjemahkan ke dalam bahasa Indonesia menjadi "mereka punya akses kepada fitur-fitur keuangan yang sehari-hari kita terima dengan mudah".

Temuan data 13:

"Indonesia mungkin ketinggalan di banyak bidang ya Infrastructure, research and development, educational system"

Data diatas merupakan campur kode yang menyisipkan wujud frasa. Terdapat bahasa Inggris yang dimasukkan kedalam bahasa Indonesia. Terdapat beberapa sisipan bahasa Inggris yang dapat di artikan satu per satu yakni Infrastructure yang berarti (prasarana), research and development yang berarti (penelitian dan pengembangan), dan educational system yang berarti (system pendidikan). Kesimpulan dari frasa diatas menunjukan sebuah pengetahuan si penutur mengenai hal-hal yang menjadi kelemahan negara Indonesia dalam menghadapi perkembangan zaman. Jika data tersbeut di terjemahkan ke dalam bahasa Indonesia menjadi "Indonesia mungkin ketinggalan di bidang prasarana, riset dan pengembangan, system pendidikan".

Temuan data 14:

"and as nation kita selalu lihat keluar, di Amerika kaya gimana ya? Eropa kaya gimana ya? Di Jepang kaya gimana ya?"

Data diatas merupakan campur kode berupa wujud frasa. Bahasa Inggris yang disisipkan kedalam bahasa Indonesia. And as nation memiliki arti "dan sebagai bangsa". Data tersebut menjelaskan mengenai rakyat Indonesia yang peduli terhadap negara, dan apa yang akan rakyat tersebut lakukan terhadap bangsa. Data tersebut di terjemahkan ke dalam bahasa Indonesia akan menjadi "dan sebagai bangsa, kita selalu lihat keluar, di Amerika kaya gimana ya? Eropa kaya gimana ya? Di Jepang kaya gimana ya?".

Temuan data 15:

"Fintech one point $O$ "

Data diatas termasuk dalam penyisipan unsur yang berwujud frasa. Data tersebut merupakan bahasa Inggris yang dicampurkan ke dalam bahasa Indonesia. data tersebut mengandung arti era dari fintech itu sendiri pada saat itu. Jika diartikan dalam bahasa Indonesia menjadi "Fintech 1.0"

Temuan data 16:

"Fintech two point $O$ "

Data diatas termasuk dalam penyisipan unsur yang berwujud frasa. Data tersebut merupakan bahasa Inggris yang dicampurkan ke dalam bahasa Indonesia. data tersebut mengandung arti era dari fintech itu sendiri pada saat itu. Jika diartikan dalam bahasa Indonesia menjadi "Fintech 2.0" 


\begin{tabular}{|c|c|c|} 
Kredo 4 (2020) \\
KREDO: Jurnal Ilmiah Bahasa dan Sastra \\
Terakreditasi Sinta 4 berdasarkan Keputusan Direktorat \\
Jenderal Penguatan Riset dan Pengembangan, \\
Kementerian Riset, Teknologi dan Pendidikan Tinggi \\
Republik Indonesia \\
Nomor: 23/E/KPT/2019. 08 Agustus 2019 \\
https://jurnal.umk.ac.id/index.php/kredo/index
\end{tabular}

\section{Penyisipan unsur yang berwujud ungkapan atau idiom}

Temuan data 17:

"But like man, kita bukan cuman liat pemandangan indah, pantai, batu bara, dan kelapa sawit"

Data diatas merupakan penyisipan berupa wujud ungakapan atau idom. Bahasa Inggris yang di sisipkan kedalam bahasa Indonesia. But like man dapat kita artikan sebagai sebuah wujud ajakan yang memiliki arti "ayolah", Dalam penjelasan diatas sang penutur mengajak lawan bicaranya melakukan sesuatu yaitu membuka pikiran kita bahwa kita bisa berkembang, dan memberitahu kita bahwa dunia tidak sekecil itu. Jika di terjemahkan ke dalam bahasa Indonesia menjadi "ayolah, kita bukan cuma liat pemdangangan indah, pantai, batu bara, dan kelapa sawit".

\section{Penyisipan unsur yang berwujud klausa}

Temuan data 18:

"and kalo kita ga ngerubah mindset kita bahwa we can actually be leaders in something and manything ya kita bakal gini-gini aja"

Data tersebut merupakan penyisipan unsur yang berwujud klausa. Data tersebut memenuhi kriteria klausa. Yakni sekurang-kurangnya mengandung predikat. Data tersebut merupakan campur kode yang mana bahasa Inggris dicampurkan ke dalam bahasa Indonesia. Data tersebut menjelaskan bahwa seharusnya pemikiran itu harus selalu berkembang dan memikirkan hal-hal yang positif. Jika data tersebut di terjemahkan maka akan menjadi "dan kalo kita ga ngerubah pikiran kita bahwa kita sebenarnya bisa menjadi pemimpin sesuatu dan banyak hal ya kita bakal gini gini aja"

Temuan data 19:

"we can do that Indonesia, but we all have to believe pasti ada jalan"

Data diatas termasuk dalam penyisipan unsur wujud klausa. Data tersebut merupakan bahasa Inggris yang di campurkan ke dalam bahasa Indonesia. data tersebut menjelaskan mengenai harapan yang baik terhadap Indonesia, karena Indonesia memiliki banyak sekali harta. Penutur menjelaskan bahwa "we can do that Indonesia" yakni kita bisa melakukanya Indonesia. data tersebut merupakan sebuah pikiran yang positif terhadap Indonesia. Lalu penutur melanjutkan tuturannya yakni "but we all have to believe" yang memiliki arti tapi kita semua harus percaya. Jika data tersebut di terjemahkan ke dalam bahasa Indonesia maka akan menjadi "kita bisa melakukannya Indonesia, tapi kita semua harus percaya, pasti ada jalan"

Penelitian ini tidak terdapat data yang menunjukkan campur kode baster, alasan tidak ditemukan campur kode baster karena tidak ditemukannya data yang memiliki ciri-ciri campur kode baster.

\section{SIMPULAN}

Berdasarkan penelitian di atas dapat disimpulkan sebagai berikut. (1) terdapat data yang merupakan bentuk campur kode yang mana terdapat penyisipan unsur yang berwujud kata adalah 8 data. Masing-masing merupakan penyisipan unsur yang berwujud kata dalam dua bahasa yakni bahasa Indonesia, bahasa Inggris. (2) dalam video youtube Agung 


Kredo 4 (2020)
KREDO: Jurnal Ilmiah Bahasa dan Sastra
Terakreditasi Sinta 4 berdasarkan Keputusan Direktorat
Jenderal Penguatan Riset dan Pengembangan,
Kementerian Riset, Teknologi dan Pendidikan Tinggi
Republik Indonesia
Nomor: 23/E/KPT/2019. 08 Agustus 2019
https://jurnal.umk.ac.id/index.php/kredo/index

Hapsah terdapat data yang merupakan bentuk campur kode yang terdapat penyisipan unsur yang berwujud frasa adalah 8 data. Masing-masing data tersebut merupakan penyisipan unsurunsur yang berwujud kata dalam dua bahasa yakni bahasa Indonesia, bahasa Inggris. (3) terdapat data yang merupakan bentuk campur kode yang terdapat penyisipan unsur yang berwujud idiom atau ungkapan adalah 1 data. Data tersebut merupakan penyisipan unsur yang berwujud ungkapan dalam dua bahasa yakni bahasa Indonesia, bahasa Inggris. (4) dalam video tersbeut terdapat data yang merupakan bentuk campur kode yang terdapat penyisipan unsur yang berwujud klausa adalah 2 data. Masing-masing merupakan penyisipan unsur yang berwujud kata dalam dua bahasa yakni bahasa Indonesia, bahasa Inggris.

Penelitian ini juga memiliki dampak positif dan negative bagi kehidupan bermasyarakat. Apakah yang mendasari pernyataan tersebut? Adanya pengaruh asing membuat kita terkadang melupakan budaya dan bahasa yang kita gunakan, bahkan lebih cenderung kepada kebiasaan-kebiasaan yang di tularkan oleh pengaruh asing tersebut. Seperti menggunakan bahasa asing yang di sisipkan kedalam bahasa Indonesia. Sisi positif dari penelitian ini adalah dengan adaanya penelitian mengenai campur kode dan sebab-akibatnya membuat kita semakin paham bahwasanya kita perlu melestarikan lagi bahasa Indonesia.

Batasan dalam penelitian ini hanya pada bentuk campur kode dalam video blog youtube Agung Hapsah. Jika peneliti lain ingin melakukan sebuah penelitian yang hampir sama dengan penelitian ini, dapat mengembangkannya kembali agar penelitian tersebut lebih spesifik dalam bagian yang berbeda, dan yang akan di kaji juga akan jauh lebih meluas dan mendalam. Dalam penelitian ini masih ada banyak yang harus di kaji dalam bagian campur kode, maka dari itu diharapkannya peneliti selanjutnya dapat menemukan permasalahanpermasalahan yang belum pernah ada. Dan semoga dengan adanya penelitian ini senantiasa menambah wawasan bagi penulis dan para pembaca sekalian.

Penelitian campur kode pada video blog youtube Agung Hapsah "fintech" dapat dijadikan sebagai referensi dasar di dalam sebuah penelitian selnajutnya. Lain itu, penelitian ini juga dapat digunakan sebagai refrensi tugas dan bahan bacaan.

\section{DAFTAR PUSTAKA}

Alawiah, Astuti. 2016. Alih Kode dan Campur Kode dalam Acara Talk Show Just Alvin di Metro TV dan Implikasinya pada Pembelajaran Bahasa Indonesia di SMA. Bandar lampung: Program Studi Pendidikan Bahasa dan Sastra Indonesia: Universitas Lampung. http://digilib.unila.ac.id/23755/12/SKRIPSI\%20TANPA\%20BAB\%20PEMBAH ASAN.pdf . 10 Mei 2020. 


Kredo 4 (2020)
KREDO: Jurnal Ilmiah Bahasa dan Sastra
Terakreditasi Sinta 4 berdasarkan Keputusan Direktorat
Jenderal Penguatan Riset dan Pengembangan,
Kementerian Riset, Teknologi dan Pendidikan Tinggi
Republik Indonesia
Nomor: 23/E/KPT/2019. 08 Agustus 2019
https://jurnal.umk.ac.id/index.php/kredo/index

Atiek Mustikawati Diyah. 2015. Alih Kode dan Campur Kode Antara Penjual dan Pembeli (Analisis Pembelajaran Berbahasa Melalui Studi Sosiolinguistik). UMP: Jurnal dimensi Pendidikan dan Pembelajaran Vol.3 No.2 Juli 2015 (23)

Badudu, J.S. 1989. Inilah Bahasa Indonesia yang Benar II. Jakarta: Gramedia Pustaka Utama.

Basrowi dan Suwandi. 2008. Memahami Penelitian Kualitatif. Jakarta: Rineka Cipta

Bromley, K. D. 1992. Languange Arts: Exploring Connection. Boston: West Publishing Company.

Chaer \& Agustina. 2014. Sosiolinguistik Suatu Pengantar. Jakarta: PT. Rineka Cipta.

Chaer, Abdul. 2003. Linguistik. Jakarta: Rineka Cipta.

Depdiknas. 2005. Kamus Besar Bahasa Indonesia. Jakarta: Balai Pustaka.

Dwi Ariyanti Riza. 2010. Analisa Alih Kode dan Campur Kode Penggunaan Bahasa Indonesia pada Percakapan Bukan Empat Mata Bulan Juli 2010. Tesis. Surakarta: Electronic Theses and Dissertation.

Hapsari, Nur Rahmi. 2018. Campur Kode dan Alih Kode dalam Video Youtube Bayu Skak. Jurnal Pena Indonesia: Univeristas Negeri Surabaya. Vol 01. http://ejournal.unipma.ac.id/index.php/widyabastra/article/view/4530/0

Kridalaksana, Harimurti. 1993. Kamus Linguistik. Jakarta: Gramedia Pustaka Utama.

Malabar Sayama. 2012. Penggunaan Bahasa Transmigran Jawa di Kabupaten Gorontalo. Gorontalo: HUMANIORA, Vol 24, No.3 Oktober 2012 (279-291)

Munandar Aris. 2018. Alih Kode dan Campur Kode dalam Interaksi Masyarakat Terminal Mallengkeri Kota Makasar. Makasar: Fakultas Bahasa dan Sastra, Universitas Negeri Makassar

Muharam Rijal. 2011. Alih Kode, Campur Kode, Dan Interferensi Yang Terjadi Dalam pembicaraan Bahasa Indonesia Dan Bahasa Melayu Ternate. Ternate: Edisi Khusus No 1, Agustus 2011

Murti Sri, 2015. Ekstensi Pengguanaan Bahasa Indonesia di era Globalisasi. Lubuk Linggau: Prosiding Seminar Nasional Bulan Bahasa UNIB 2015. 


Kredo 4 (2020)
KREDO: Jurnal Ilmiah Bahasa dan Sastra
Terakreditasi Sinta 4 berdasarkan Keputusan Direktorat
Jenderal Penguatan Riset dan Pengembangan,
Kementerian Riset, Teknologi dan Pendidikan Tinggi
Republik Indonesia
Nomor: 23/E/KPT/2019. 08 Agustus 2019
https://jurnal.umk.ac.id/index.php/kredo/index

Nababan, P.W.J. 1991. Sosiolinguistik Suatu Pengantar. Jakarta: PT Gramedia Pustaka Utama.

Nisa Khoiru, Suyitno Imam. 2017. Kesalahan Penggunaan Bahasa Indonesia dalam Teks Terjemahan Mahasiswa. UNM: BASINDO, Jurnal Kajian Bahasa, Sastra Indonesia, dan Pembelajaranya. Vol 1 No.1-April 2017 (1-13).

Nurmina, Aflah Nurul. 2017. Analisis Bahasa Campur Kode dalam Lirik Lagu Bergek. Bireuen: Jurnal Pendidikan Almuslim. No 3 Mei 2017.

Nurwani Nanik. 2016. Analisis Campur Kode dalam Iklan. Prosiding Seminar

Ode Marni Wa. 2016. Campur Kode dan Alih Kode Dalam Peristiwa Jual Beli di Pasar Labuan Tobelo Kecamatan Wakorumba Utara Kabupaten Buton Utara. Tobelo: Jurnal Bastra (Bahasa dan Sastra), Vol 2 No 1 Juli 2016

Prasanti Suminar, Ratna. 2016. Pengaruh Bahasa Gaul Terhadap Pengguna Bahasa Indonesia Mahasiswa UNSWAGATI. Universitas Swadya Gunung Jati: Jurnal Logika, vol XVIII, No 3 Desember 2016

Rahardi, Kunjana. 2010. Kajian Sosiolinguistik Ihwal Kode dan alih Kode. Bogor: Ghalia Indonesia.

Rokhman, Fathur. 2013. Sosiolinguistik: Suati pendekatan Pembelajaran Bahasa dalam Masyarakat Multikultural. Yogyakarta: Graha Ilmu.

Ruyaldi, Rohmadi Muhammad, Tri Sulistyo Edy. 2014. Alih Kode Dan Campur Kode Dalam Pembelajaran Bahasa Indonesia Di SMA. UNS: Jurnal Paedogogia, Vol.17 No.1 Tahun 2014

Samosi, Astuti. 2019. Campur Kode dan Etnografi dalam Interaksi Tawar di Pasar Simpang Tigo. UIP: Jurnal Kredo, Vol 2 No. 2 April 2019.

Satya Hermawan Gede. 2014. Analisis Sintaksis campur Kode Jepang-Inggris Pada Lirik Lagu Puzzle Karya Aika Ohno. Singaraja: PRASI Vol 9, No17 Januari-Juni 2014

Srihartatik Atik, Mulyani Sri. 2017. Alih Kode dan campur Kode masyarakat Tutur Di Pasar Tradisional Plered Cirebon. Cirebon: Jurnal Literasi, Vol 1 No 2 Oktober 2017

Sudaryanto. 2016. Metode dan Aneka Teknik Analisis Bahasa. Yogyakarta: USD

110 | Jurnal Kredo

Vol. 4 No. 1 Oktober 2020 


\begin{tabular}{|c|c|c|} 
Kredo 4 (2020) \\
KREDO: Jurnal Ilmiah Bahasa dan Sastra \\
Terakreditasi Sinta 4 berdasarkan Keputusan Direktorat \\
Jenderal Penguatan Riset dan Pengembangan, \\
Kementerian Riset, Teknologi dan Pendidikan Tinggi \\
Republik Indonesia \\
Nomor: 23/E/KPT/2019. 08 Agustus 2019 \\
https://jurnal.umk.ac.id/index.php/kredo/index
\end{tabular}

Sudaryanto. 1988. Metode Linguistik (Bagian Pertama: Ke Arah Memahami Metode Linguistik). Cetakan ke 2. Yogyakarta: Gajah Mada University Press.

Suhardi. 2009. Pedoman Penelitian Sosiolinguistik. Jakarta: Pusat Bahasa.

Suwito. 1989. Sosiolingusitik, Pengantar Awal. Surakarta: Hanary Offset.

Susmita Nelvia. 2015. Alih Kode dan Campur Kode Dalam Pembelajaran Bahasa Indonesia Di SMP NEGERI 2 KERINCI. Jambi: Jurnal Penelitian Universitas Jambi Seri Humaniora.

Wardhani Pramika, Mulyani Mimi, Rokhman Fatur. 2018. Wujud Pilihan Bahasa dalam Ranah Keluarga pada Masyarakat Perumahan di Kota Purbalingga. UNS: Jurnal Kredo, Vol 2 No. 2 April 2018.

Widianto, Eko. 2018. Pemertahanan Bahasa Daerah Melalui Pembelajaran dan Kegiatan di Sekolah. UMK: Jurnal Kredo. Vol 1. No 2. 